per cent of the Earth's $\mathrm{O}_{2}$. Hence, although the oceanic reservoir strongly buffers atmospheric $\mathrm{CO}_{2}$ changes, it has little impact on the atmosphere's $\mathrm{O}_{2}$ content. Because of this the authors can directly compare the magnitude of the atmospheric $\mathrm{O}_{2}$ decrease with that required for the combustion of coal, oil and natural gas during the 3-year period spanned by their measurements. Their conclusion is that the $\mathrm{O}_{2}$ decrease is consistent with the fossil fuel demand: there is no need to call upon either a net production or net consumption of $\mathrm{O}_{2}$ by the biosphere.

In other words, global greening appears to be compensating for losses by deforestation and agriculture. This implies that the ocean must be taking up all the $\mathrm{CO}_{2}$ derived from fossil fuels that does not stay in the atmosphere, about 3 gigatonnes of carbon each year. Keeling and Shertz stress, however, that the uncertainty in their estimate of the rate of change in the amount of carbon stored in the terrestrial biosphere is as yet too large to permit firm conclusions to be drawn as to whether this reservoir is a net source or sink for $\mathrm{CO}_{2}$. Only when the record covers a decade will the accuracy of the trend be sufficient to make this distinction.

While waiting for their record to grow to the desired length, Keeling and Shertz have taken on a second application of their technique. It struck them that the magnitude of the seasonal cycle in the $\mathrm{O}_{2} / \mathrm{N}_{2}$ revealed by their measurements could be harnessed to place limits on the amount of plant matter which falls from the surface ocean into the dark interior (Fig. 1). Biological oceanographers call this quantity new production in order to distinguish it from the total amount of organic matter formed by photosynthesis. New production is considerably less than total production because much of the photosynthetic product is recycled by animals and bacteria living within the sunlit upper ocean. Only that portion of the organic matter which escapes the mixed layer by falling (or swimming) into the sea's interior contributes to the cycles in the sea's nutrient constituents and to the atmosphere's $\mathrm{O}_{2}$ content.

The magnitude of new production in the ocean has in recent years become a subject of considerable debate. Geochemists using isotopic clocks ${ }^{4}$ estimate higher values than the traditional ones obtained by biologists using the results of ${ }^{14} \mathrm{C}$ - and ${ }^{15} \mathrm{~N}$-tagged incubations (refs 5,6 , respectively).

Keeling and Shertz again exploit the fact that the ocean's carbon system strongly buffers changes in $\mathrm{CO}_{2}$. The seasonal extraction of $\mathrm{CO}_{2}$ from surface waters by marine photosynthesis is so buffered that it makes no discernible imprint on the atmosphere's $\mathrm{CO}_{2}$ conNATURE · VOL 358 • 27 AUGUST 1992

\title{
Grave guardians with a difference
}

\begin{tabular}{|c|c|}
\hline $\begin{array}{l}\text { EvaLuATING the condition } \\
\text { of a collection of } \\
\text { wooden figurines from } \\
\text { the Pacific Northwest of } \\
\text { America, Robert A. Blan- } \\
\text { chette and colleagues } \\
\text { found that things were } \\
\text { not quite what they } \\
\text { seemed (Mycologia } 84 \text {, } \\
119-124 ; 1992 \text { ) } \\
\text { many of the objects were } \\
\text { in fact carved from the } \\
\text { fruiting body of the } \\
\text { wood-destroying fungus } \\
\text { Fomitopsis officinalis. } \\
\text { With hindsight, the find- } \\
\text { ing might have been } \\
\text { expected. The fungus, } \\
\text { known to some of the }\end{array}$ & $\begin{array}{c}\text { IMAGE } \\
\text { UNAVAILABLE } \\
\text { FOR COPYRIGH } \\
\text { REASONS }\end{array}$ \\
\hline
\end{tabular}

native American tribes as the bread of ghosts, featured large in their culture and was attributed with supernatural powers. Indeed, the collection of the Field Museum of Natural History, Chicago, includes an uncarved fruiting body (sporophore) which had been used as a poultice to relieve swell-

ings and inflammations. Found in coniferous forests, $\boldsymbol{F}$. officinalis may have been collected by shamans ('medicine men') during retreats which they took "to encounter the spirits". The carved spirit figures now examined by Blanchette and colleagues had been collected from the late 1800 s from shaman graves, where they had presumably been placed as guardians. Horizontal striations across the figures, due to the annual accumulations to the perennial sporophores, must have been mistaken for tree rings by collectors, reinforcing the incorrect conviction that the objects were fashioned from wood. Blanchette and colleagues have already identified 13 fungal carvings from five museums.

R.P.

tent. They demonstrate this through a comparison of the atmospheric $\mathrm{CO}_{2}$ and $\mathrm{O}_{2}$ cycles in the Northern and Southern Hemispheres (Fig. 2). Because of the seasonality in terrestrial photosynthesis, the land-rich Northern Hemisphere's atmosphere shows distinct seasonal cycles for both $\mathrm{O}_{2}$ and $\mathrm{CO}_{2}$. Because about half the Northern Hemisphere's photosynthesis is on land and about half in the sea the amplitude of the $\mathrm{CO}_{2}$ cycle is about half that for the $\mathrm{O}_{2}$ cycle. By contrast in the land-poor Southern Hemisphere, there is only a barely discernible $\mathrm{CO}_{2}$ cycle but a large $\mathrm{O}_{2}$ cycle. While the magnitude of the $\mathrm{O}_{2}$ cycle has the potential to constrain estimates of new production in the ocean, Keeling and Shertz point out that optimal use of this information will require corrections for dilution through atmospheric mixing (both vertical and meridional), for the seasonal overlap between the upwelling of $\mathrm{O}_{2}$-deficient deep water and the $\mathrm{O}_{2}$ supply by new production and for the contribution of terrestrial photosynthesis especially in the Northern Hemisphere.
Humanity owes much to the Keeling family. Throughout his scientific career, father Charles David has made ultraprecise measurements of $\mathrm{CO}_{2}$ in the atmosphere and ocean which provide the base upon which our ideas regarding the fate of fossil fuel $\mathrm{CO}_{2}$ are constructed. Now son Ralph has launched a complementary $\mathrm{O}_{2}$ measurement programme that will probe a serious unanswered question concerning the Earth's current carbon budget.

Wallace S. Broecker and Jeffrey P. Severinghaus are at the Lamont-Doherty Geological Observatory, Palisades, New York 10964, USA

\footnotetext{
1. Keeling, R. F. \& Shertz, S. R. Nature 358, 723-727 (1992).

2. Houghton, J. T., Jenkins, G. J. \& Ephraums, J. J. (eds) Climate Change: The IPCC Scientific Assessment (Cambridge University Press, 1990).

3. Tans, P. P., Fung, I. Y. \& Takahashi, T. Science 247. 1431-1438 (1990)

4. Jenkins, W. J. \& Goldman, J. C. J. mar. Res. 43 465-491 (1985).

5. Eppley, R. W. \& Peterson, B. J. Nature 282, 677-680 (1979)

6. Dugdale, R. C. \& Goering, J. J. Limnol. Oceanogr. 12 196-206 (1967).
} 